NBER WORKING PAPER SERIES

\title{
TAXATION AND CORPORATE PENSION POLICY
}

\author{
Irwin Tepper \\ Working Paper No. 661 \\ NATIONAL BUREAU OF ECONOMIC RESEARCH \\ 1050 Massachusetts Avenue \\ Cambridge MA 02138
}

April 1981

The research reported here is part of the NBER's research programs in Pensions and Taxation. Any opinions expressed are those of the author and not those of the National Bureau of Economic Research. 
Third Revision

$9 / 23 / 80$

Taxation and Corporate Pension Policy

Irwin Tepper

Harvard University

\section{Introduction}

As a result of rapid growth in the post-war period, pension plans have become a major component of the financial structure of large corporations. A recent survey [5] of 475 of the Fortune 500 companies revealed that pension cost in 1978 averaged $12.5 \%$ of pretax profits and $7.2 \%$ of wages and salaries. Vested liabilities and pension assets averaged $34 \%$ and $26 \%$ of book net worth, respectively. ${ }^{1}$ Given a typical debt/net worth ratio of 40\% this data implies that pension assets for this group of companies approximate $19 \%$ of corporate assets and vested liability is $85 \%$ of 1 ong term corporate liability. ${ }^{2}$ Despite these magnitudes, pension items do not appear on the corporate balance sheet and little has been known about how pension decisions are and/or should be made. ${ }^{3}$

In the past few years there has been a growing interest in pension policy from a financial management viewpoint. 4 At one end of the spectrum of available literature there is the analysis of corporate pension funds under the assumptions of perfect markets and equal access. ${ }^{5}$ For example,

${ }^{\star}$ I am grateful to Fischer Black, (especially), William Sharpe, Jay Light, William White and participants in the Finance Research workshop at the Harvard Business School for helpful discussion and suggestions.

Market values were close to book values at this time.

2 The ratios for individual companies vary significantly.

3 Treynor, eta1 [11] have demonstrated the importance of integrating the balance sheets of corporations and their pension funds in analyzing the capital structure of firms and the value of each claim.

${ }^{4}$ This has arisen in part from the growth of the private pension system and in part from the public policy concerns as reflected in the Employees Retirement Income Security Act of 1974 (ERISA). The act regulates various aspects of the major policy decisions facing the corporation; ( 1 ) benefit provisions, (2) funding and (3) investment of pension fund assets. It ilso established the Pension Benefit Guarantee Corporation (PBGC) which is a quasi-government corporation that insures pension benefits and has the power within limits to assess corporations for funding deficiencies in the event of a plan termination. 5 See Fama [3] for a review of this framework. 
Sharpe [8] demonstrates that funding and investment policy will have no effect on the value of the total compensation of employees-current plus deferred wages (pensions)--so long as employees are rational, the capital market is perfect and individuals and firms have equal access to it. In this world the firm will have to pay the price of providing risk-free pension promises; if the funding and investment strategy is risky, then employees or the Pension Benefit Guaranty Corporation will demand that the firm acquire insurance to protect their claims or pay them excess current wages so that they can acquire it themselves. When the value of the compensation package is fixed, as it is in Sharpe's case, Black [1] has shown that

the level of funding and the investment policy should not affect shareholder value. This comes about because investors can offset any corporate asset/1iability decision on personal account. This conclusion can be expanded to a world of uncertainty, including the possibility of corporate bankruptcy and/or pension plan termination so long as claimants on the firm (i.e. shareholders, beneficiaries, bondholders) protect themselves from one another with costlessly enforced me-first rules which ensure that the characteristics of the payoffs on the firm's outstanding claims are unaffected by changes in financial policy (see Fama [3] for the argument as applied to capital structure decisions). The special tax status of corporate pension plans is a major factor that is ignored in the perfect markets assumptions underlying these results. In [9] Tepper and Affleck concluded that, given the tax status of corporate pension plans, a firm could enhance shareholder value by borrowing to fund the pension plan. This strategy would produce an arbitrage situation within the firm whereby the pension fund would earn a pretax rate of return while the firm would pay tax-deductible interest on the financing. ${ }^{6}$ Creditors should ruptcy and the priority of claims; these will be discussed in later sections of the present paper). 
not object since, when the balance sheets of the pension fund and the company are integrated, the net leverage after taxes is decreased. The only loser is the government. The paper also concluded that an equityfinanced investment of debt in the pension fund would not produce economic benefits. This strategy omits the tax deduction of interest charges at the corporate level which produced the arbitraged returns in the debt-financed strategy. Since the only difference between the two funding strategies is the source of financing, the results have to be attributable to an assumed economic benefit of leverage. Given recent research in the area of corporate capital structure this is a questionable assumption and any results based upon it must be reevaluated.

The Tepper-Affleck paper utilized the Modigliani-Miller (MM)

world with corporate taxes (but with no differential personal tax rates on debt and equity returns). This is a troubling framework because, without the introduction of bankruptcy costs or other imperfections, the firm should have all debt and no equity in its capital structure. The case of equity financing an investment in the pension fund would not even be a relevant alternative. More importantly, the limitations of the MM framework as a robust theory of capital structure have been widely recognized. Therefore, any conclusions regarding corporate pension policy that are based upon it should be suspect. As will been shown below, and contrary to the conclusions of the Tepper-Affleck results, when a more general framework is used, the source of financing is not the important factor is assessing the desirability of pension funding; equity is almost as good as debt.

A second tax-related question has arisen. The Tepper and Affleck paper analyzed a pension fund investment in debt. Would the advantage to funding still prevail if the pension fund were invested in equities? At 
present equities account for approximately $50 \%$ of pension fund investments and have ranged from a low of $19 \%$ in 1950 to a high of $74 \%$ in 1972 . As discussed above, in the MM framework the advantage to pension funding was attritutable to the tax advantage of leverage. Hence, this advantage would exist regardless of what the pension fund was invested in. In contrast, in the more general framework used in this paper, tax advantages exist only when the pension fund is invested in debt.

Finally, the main result of the paper rested upon the assumption that the contribution to the pension fund was fully deductible at the time it was made. The paper did not consider in detail what the consequences of not taking an immediate deduction would be and, as it turns out, this is an important practical case if a firm attempted to continually fund above the level of tax-deductible contributions that is allowed by the Internal Revenue Service. ${ }^{7}$ This question is dealt with in the Appendix.

These issues will be elaborated on below. In Section II the effects of the tax structure on the desirability of having pension plans and on the funding and investment policies of such plans is discussed. A setting is used in which pension fund earnings are exempt from corporate taxation (this assumption is justified in the Appendix) and the personal tax rate on equity returns is less than the personal tax rate on bond returns. The Miller [6] case in which there is no tax advantage to corporate leverage is thus encompassed. The major results of the analysis are that pension plans should be fully funded and invested totally in bonds as opposed to equities (contrary to current practice). ${ }^{8}$ These results follow from the fact that the return on debt held in a corporate pension fund is passed through the firm to the shareholder and is 
taxed at the lower personal tax rate on equities; the shareholder will pay less taxes than if the debt were held in his personal portfolio. As a result the shareholder is better off if the pension funds of the corporations he invests in maximize their bond commitments through funding and investment policies and he minimizes them in his personal portfolio. The shareholder should directly invest in the equities he wishes to hold and the pension funds of the companies he invests in should not.

The conclusions of this paper are based on the portfolio structure principles discussed above, not on leverage. Even when there is no tax advantage to debt the optimal both policy permits the investor to have the debt/equity exposure he desires and minimizes his taxes. As will be shown below, the tax benefits of funding that stem from taking maximum advantage of differential personal tax rates on debts and equities are larger than any tax benefit that is attributable to corporate leverage.

Section III discusses the discrepancies between the prescriptions presented above and current practice. In general, it is found that while corporations do take advantage of the tax benefits by establishing qualified pension plans they do not maximize the benefits obtainable in establishing financial policies for the plan. Pension policy is guided mostly by considerations involving a breakdown (either real or perceived) in other aspects of the perfect markets/equal access assumptions.

The Appendix contains a detailed analysis of each of the two tax provisions that apply to corporate pension plans. Taken together, these provisions permit the firm to earn the pretax rate of return on its pension fund investments, i.e. they result in a complete exemption from taxes on income: this result is used throughout the paper. Each provision by itself permits a deferral of taxes, The deferrals amount to interest free loans from the government, and 
the economic benefits that the company derives stem from its ability to earn interest on these deferrals. It is shown that the sum total of the economic benefits of these deferrals is a complete tax exemption for the pension fund income, and that a fairly long time horizon is required before the economic benefits become significant.

\section{Tax-Ind zed Effects on Corporate Pension Policy}

Corporate pension plans have two major tax provisions: (1) earnings in the fund are not taxed, (2) contributions to the pension fund (subject to maximum limitations) are deductible immediately. As shown in the Appendix these provisions result in a complete exemption of earnings on the pension fund from corporate taxes; i.e. the pension plan earns the pretax rate of return. These tax provisions have implications for the full spectrum of corporate pension policies; (1) funding, (2) investment, (3) benefit provisions.

In this section each of these areas will be discussed. With the exception of the tax treatment, a perfect market framework is employed in which it is permissible to think of pension portfolios as an integral part of the personal portfolios of the shareholders of the firm. ${ }^{9}$ With equal access, investors can take positions that offset pension investments. In the tax area, Miller's [6] world of different personal tax rates on equities and bond returns is incorporated.

9 This analysis assumes that the firm is a going concern over the horizon of these contracts. It therefore ignores the risk elements introduced by the possibility of bankruptcy and/or plan termination (see Treynor, etal [11]). In general, funding the pension system worsens both the bondholders and the stockholders position, but while not treated in this paper, the tax. benefits probably swamp these effects. 
Funding and investment policy will be treated as interrelated financial dectsions; the value of funding depends on whether the fund is invested in stocks or bonds. The results will be stated in terms of the economic gains to the shareholders as was done by Miller. In all cases treated, a fully hedged position will be created and the net returns to the shareholder, if any, will be risk-free. The economic gain will be these returns capitalized at the after-tax rate of return on personal debt holdings. This is equivalent to the approach used by Miller and to his assumption that the streams are perpetuities. The latter requires that the financial policies analyzed are put in place on a permanent basis. (More will be said about this in Section III.).

The general principles underlying the analysis are that 1 ) the return to shareholders of a debt investment in the pension fund is passed through the corporation and is taxed at the personal tax rate on equities. Hence, so long as the personal tax rate on equities is less than the personal tax rate on debt, shareholders would prefer to have their bondholdings in the corporate pension fund as opposed to being held in their personal portfolios; 2) the choice of financing a pension fund investment hinges on the familiar analysis of where shareholders prefer to borrow--at the corporate level or at the personal level. As Miller has stated, with a low personal tax rate on equities the decision depends upon a comparison of the corporate tax rate with the personal tax rate on bonds. The case where there is no tax advantage to corporate leverage is highlighted in the discussion that follows.

The conclusions that are reached from the analysis below are 1) the pension plan should always be funded and debt should be the investment vehicle, so long as personal tax rates on equities are less than that 
on debt; 2) debt financing would always be optimal; equity financing would be inferior only if there is a positive value to corporate leverage. If the clientele effect is operating there will be no optimal financing policy. Case 1: Debt investment; debt financed

The debt investment in the pension fund does not necessitate an offsetting transaction in personal portfolios since it has been offset at the corporate level. The economic gain (see Table 1) depends upon the personal tax rates on debt and equity returns and the corporate tax rate. In equilibrium they will all be interrelated. When they have values such that there is no tax advantage to corporate leverage, the after-tax cost to the shareholder of corporate debt $\left[\left(1-\tau_{c}\right)\left(1-\tau_{p s}\right)\right]$ is equal to the after-tax return (cost) of personal lending (borrowing) $\left[1-\tau_{\mathrm{pb}}\right]$. When this is true, the shareholder is indifferent between the company issuing debt and he/she selling bonds or taking out a loan to finance the investment in the pension fund. The value of this strategy in this case is simply the value of having the corporation invest the pension fund in bonds and passing the returns through to the shareholders at the personal tax rate on equities. This value is identical to Case 3 below.

Case 2: Equity investment; debt financed

In this case, the equity investment in the pension fund increases the shareholder's total equity holdings. The increase can be offset by reducing equities held in his/her personal portfolio. There are notax effects since the return on equity is taxed at the personal tax rate whether equities are held in the pension fund or in the investor's portfolio. Equity investments in the pension fund do nothing for the shareholder. The debt that is taken on to finance this position must now be offset in personal portfolios. Hence, this strategy would not have any value when there is no value to corporate leverage. 
Table 1: Economic Gain of Funding for Different Investment and Financing Decisions

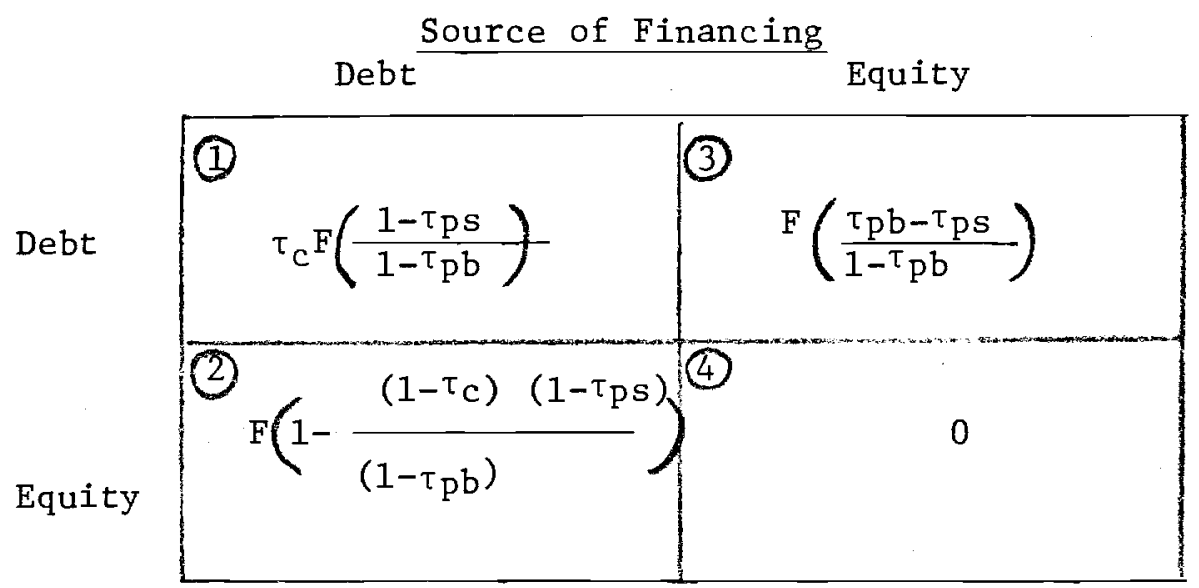

Notes: I. $\quad F \equiv$ Amount funded

$\tau \equiv$ Corporate tax rate

$\tau_{\mathrm{ps}}^{\mathrm{c}}=$ Personal tax rate on equity returns

$\tau \mathrm{pb} \equiv$ Personal tax rate on bond returns

II. (1) $-(3)=$ (2) the value of corporate leverage.

(1) $-(2)=(3)$ the value of debt holding in the pension fund vs in personal portfolios.

III. When there is no value to corporate leverage, (2) equals zero. Hence $\left(1-\tau_{p b}\right)=\left(1-\tau_{c}\right)\left(1-\tau_{p s}\right)$. This relationship can be solved for $\tau_{c}$ and substituted in (1) to show that it is equal to (3) Alternatively it can be substituted in (3) to show that the economic gain is equal to $\left(\frac{{ }^{\tau} c}{1-\tau}\right)_{c}^{F}$. This value is greater than the value in the disequilibrium MM world $\left(\tau_{c} F\right)$ See [9], [10]. 
Table 1: Continued

\section{Derivation of Formulas:}

Let $F_{S} \equiv$ dollar amount of pension fund investment in equity

$F_{D} \equiv$ dollar amount of pension fund investment in debt

$L \equiv$ additional corporate debt issued to finance pension fund investments

$r$ = market interest rate

$\rho \equiv$ return on equity (can be expanded to deal with a portfolio of individual securities; i.e. can be made a vector of returns)

To derive the economic gains from pension funding, start from a position where $F_{S}, F_{D}$, $L$ all equal zero. A non-zero position taken by the firm in any $o$. these will be offset in personal portfolios to produce a complete arbitrage. The economic gain to the shareholder (after-tax) is the return on the pension portfolio, less the cost of additional corporate debt used to finance the investments, less the costs/returns due to offsetting transactions in the personal portfolio, all discounted at the after-tax risk-free rate: i.e.,

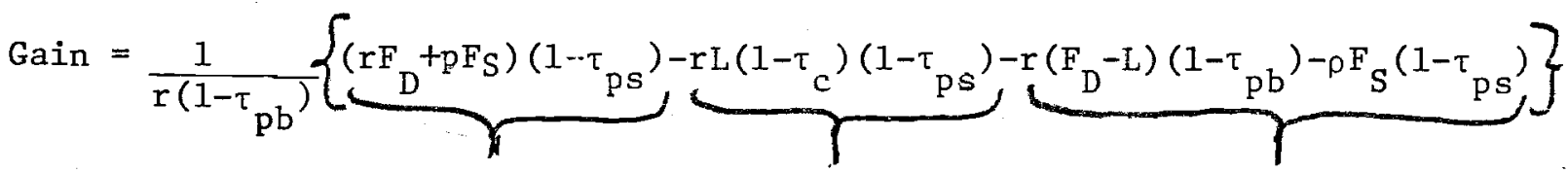

$$
\begin{aligned}
& \text {, return on pension cost of corporate costs/returns of } \\
& \text { portfolio. leverage }
\end{aligned}
$$

This general expression can be used to derive the formulas in the table.

To derive formula 3 , for example, Let $F_{D}=F, F_{S}=0, L=0$; then the gain equals, $\frac{1}{r\left(1-\tau_{p b}\right)}\left\{(r F+0)\left(1-\tau_{p s}\right)-0-r F\left(1-\tau_{p b}\right)-0\right\}=\frac{F\left(\tau_{p b}-\tau p s\right)}{\left(1-\tau_{p b}\right)}$ 
If there is a tax-induced reason to increase corporate leverage relative to equity it would be more efficient to do so with a capital structure change as opposed to borrowing and putting the money in pension fund equities. The latter would increase the exposure of the shareholders and would require that the latter engage in unnecessary offsetting transactions.

Case 3: Debt investment; equity financed

This strategy involves reducing the amount of investible funds in shareholder portfolios. Since debt is being held in the pension fund the shareholder would reduce his holdings of debt in order to maintain a constant total portfolio structure (i.e. personal plus pension fund holdings). As in Case $I$, this transaction has the effect of altering the taxation of the returns on portfolio debt; the returns would now be taxed at the personal tax rate on equities as opposed to the personal tax rate on debt. It is only valuable to the shareholder when the personal tax rate on equity is lower than that of debt. Its value is identical to the value in Case 1 when there is no value to corporate leverage; i.e. the bond investment strategy has a positive value independent of its financing (see footnote III to Table 1).

\section{Case 4: Equity investment; equity financed}

The strategy simply involves substituting equities held on personal account for equities held in the pension fund. As discussed in the discussion of Case 2 there areno tax induced gains. 10

${ }^{10}$ This result was elaborated on by Scholes [7]. 


\section{Benefit Policy}

The tax considerations used above are helpful for assessing whether the firm should have a pension plan and/or a liberal policy with respect to granting pension benefits. A simplified model will be used in which the pension obligation is simply a deferred wage. This approach does not factor in any incentive effects that may exist with respect to certain benefit schemes - e.g. final average pay plans - that (especially) salaried workers often have. 11 It a 1 so does not consider the effects of the shifting of risks from the firm to the employee if a corporate-funded defined benefit plan is dropped in favor of an employee funded plan which is essentially a defined contribution plan. With these caveats in place, the firm's benefits policy is determined by the decision regarding how much pension liability to issue.

Following Sharpe [8], it will be assumed that employees are rationa1 and are willing to make tradeoffs between current wages and deferred wages paid out as pensions so long as their economic position is not deteriorated. With the establishment of Individual Retirement Accounts (IRA's) in 1974 as part of ERISA, employees of a firm that does not have a pension plan can set up their own and receive the same tax status as corporate pension plans - i.e. deferral of taxes on contributions and deferral of taxes on earnings in the retirement plan. Therefore, the employee will earn the same pre-tax rate of return the firm does and would use a pretax risk-free rate of return in establishing current/deferred wage tradeoffs ${ }^{12}$ The other side

11 The existence of incentives has been questioned. In a rational economic model only the deferred wage aspect can be identified. See Sharpe [8]. markets and, for simplicity, comparison of alternatives is made uniformly at the risk-free rate. 
of this is that the risk-adjusted cost of funds raised by the firm via issuing pension liabilities is the pre-tax rate of return. Since the firm earns the pretax rate on pension assets the best it can do is to stay even either by having a fully funded pension plan or by having no plan at all and letting the employees establish IRA's.

In this simple analysis certain factors have been omitted. For example, it has been implicitly assumed (as was done in the analysis of corporate plans) that no changes in the employee's tax rate takes place from the time contributions are made to the time they are withdrawn. If the tax rate at which contributions are made is higher than the tax rate applied to withdrawals then the employee would be willing to accept a lower rate of return. It is almost certain that the tax rate will decline at the time the employee retires since retirement income does not usually equal income just prior to retirement. However, the employee will be making contributions to the IRA throughout his lifetime and it is not clear that, on balance, he/she will be contributing at a higher rate than the rate that would apply during the withdrawal period. In the earlier years of the career, real income and investible wealth will be lower; for home owners their deductions will be higher. Add to that the effects of inflation on the individual's tax bracket and it is not at all clear whether, on balance, the tax rate in the accumulation period is higher or lower than the rate in the decummulation period. To the extent that it is higher, the benefit of a pension plan will be diminished but not eliminated.

Another factor which might affect the employee's position is the $\$ 1500$ limit on contributions to the IRA. This limit would be reached for high-salaried employees if the formulas determining the level of contribution 
were based on reasonable replacement ratios for income in retirement. Congress is currently studying increases in IRA limits so that this may not be a factor in the near future.

With these caveats in mind, unfunded pension liability is likely to be an expensive source of funds relative to debt if employees evaluate their opport"nities rationally. Pension plans are encouraged by the tax structure and employees can provide them for themselves or go to a company that does.

III. Concluding Remarks

Corporate pension policies in practice today diverge significantly from the prescriptions presented above. As the data at the beginning of this paper indicate, firms have raised a substantial amount of funds through the issuance of pension liabilities. They do not appear to maximize the funding of their pension systems and they invest a substantial portion of the fund (currently about 50\%) in equities. Some explanations of these phenomena are presented below.

Unfunded pension liabilities would be a costly source of funds because competing firms would take advantage of the tax structure and would provide fully funded plans. In the absence of competitors, the employees could establish an IRA and take advantage of the tax provisions themselves. The IRA type of pension scheme came about as part of ERISA in 1974, long after most firms established their plans and accumulated the bulk of the existing liabilities. Prior to 1974 the tax situation was more favorable to corporate pension schemes in that employees would have accepted a lower rate of return between current wages and supplements and deferred pension benefits. The fact that the company bears the investment risk in 
defined benefit plans, not the employees, would also be an important factor if the choice was between a company plan and an IRA.

While it is often said that firms minimize their pension outlays, this is not true. The majority of firms use actuarial procedures that produce a required pension contribution in excess of the minimum they could get away with. Among the several actuarial cost methods that are acceptable, the one that produces the lowest level of contributions is designed to fund benefits as they accrue. Most firms elect one of the other, more liberal methods and hence pre-fund benefit accruals. In addition to higher costs, this procedure results in a buildup of a relatively permanent level of assets in the pension fund in excess of what is needed to cover benefit accruals (see Trowbridge [12]). In addition, many firms use conservative actuarial assumptions and this has the effect of further prefunding benefits.

The result is that many firms do accelerate funding by the choice of methods and assumptions over long time periods and this results in significant tax-induced gains. However, considerations other than the tax structure dominate this decision. The two most-often mentioned are benefit security and cost stabilization. The actuarial profession has been the dominant force in promoting these considerations and in developing the pension cost procedures that produce "reserves" which make satisfaction of these goals possible. It is true, however, that within the established actuarial framework, firms typically minimize pension contributions. Changes in funding in this instance would not be permanent and hence would not accumulate to the maximum possible tax benefit (see Jackson [4]).

A number of explanations exist as to why firms do not consider the tax benefits to be a major factor. First, even though in the general equilibrium analysis presented in this paper there will be an advantage to shareholders 
even if corporate tax rates change, managers who focus on their own company's financial performance will be concerned about such a possibility. In general, falling corporate tax rates will be good and rising corporate tax rates will be bad. Inflation and other social/economic effects will cause rates to rise but tax legislation can lead to reductions. It is not clear what corporate tax rates will be over the long run. Secondly, prefunding the pension system enhances the economic position of the participants to the detriment of the suppliers of capital, since the wealth in the pension fund cannot be brought back into the firm. Thirdly, the firm may be resource-constrained; i.e. it may not be able to freely raise the capital needed internally and also fund the pension plan. This argument runs counter to the perfect markets assumptions utilized above. Fourthly, it is often argued that pension fund investments have not kept pace with inflation and hence that it is poor investment. This argument fails to consider the inflation-induced gains on the financing side of pension fund investments. In the arbitraged scheme utilized in this paper, gains and losses due to inflation are fully hedged. (For a further discussion the points raised in this paragraph see [9] and [10].).

Fina11y, the investment of pension fund assets in equities can only be rationalized by appealing to violations of the perfect markets assumptions émployed herein and/or to the failure of management to consider and understand the value of having bonds in the pension fund given the economic opportunities of its shareholders. These problems are central to many issues in corporate finance and are not dealt with herein. 
Appendix

Taxes and Rates of Return on Pension Fund Investments

The bulk of corporate pensions are qualified by the Internal Revenue Serivce to receive special tax treatment. Specifically, contributions to the pension fund, subject to maximum limitations, are deductible at the time they are made and earnings on pension fund investments are not taxed. When the maximum deductible limit is not constraining the corporation earns the pension fund's pre-tax rate of return on the investment of its contributions. The return comes in the form of reduced pension contributions in the future. The purpose of this appendix is to examine each of the tax provisions. separately and to assess their relative importance.

It is important to recognize that each of the two tax provisions taken separately results in a deferral of taxes (but that together they amount to a complete exemption of pension fund income from tax). A11 contributions to the pension fund will eventually be deductible as a business expense. If a deduction is taken when a contribution is made then that deduction cannot be taken in the future. Hence, current taxes are reduced and future taxes are increased. ${ }^{13}$ Similarly, not paying taxes on pension fund earnings at the time they are earned will result in an eventual tax payment on these earnings. At some point in the future, contributions to the plan will be reduced by an amount equal to the accumulation of untaxed income (assuming the plan's liabilities are unchanged).14 At that time taxable income will increase by this amount and hence taxes will be paid. on it. These deferrals are interest free loans from the government and the general rule is that the gain to the firm is equal to the after-tax interest that accumulates on the deferral. 13 This is analogous to tax shelter deals. ${ }^{14}$ The funding patterns and the adjustments made to them as a result of altering contribution schedules and/or the accumulation of pension fund earnings are determined by the plan's actuarial cost methods. 
In measuring the amount of the economic benefit of these deferrals a bond investment in the pension fund is assumed and the benchmark used will be that of a riskless corporate investment where the firm pays taxes on returns in each period and, therefore, earns the after-tax rate of return. 15 The first situation considered is where the deferral of taxes on pension fund investment earnings is permitted but where deductions of contributions cannot be taken when the contribution is made. ${ }^{16}$ The contributions will accumulate in the pension fund at the (pretax) rate of return and at some point in the future contributions will be reduced--and pretax profits will increase--by this accumulated value. At that time the company will receive a deduction for the contribution it initially made so that it would only pay tax on the accumulated earnings in the fund. Using a simplified framework, let,

$r \equiv$ the (pretax) rate of return in the pension fund; assumed to be in bonds for comparison with a riskless corporate investment.

$\mathrm{n} \equiv$ the year in which contributions are reduced by the pension fund accumulation on a contribution made at time 0 . $\tau_{c} \equiv$ corporate tax rate.

Then, for a dollar invested in the pension fund the firm earns, after-tax, $(1+r)^{n}-\tau_{c}\left[(1+r)^{n}-1\right]$ over the period of $n$ years. The value of the $t a x$ deferral of earnings is the difference between this amount and the amount that would have been accumulated if the dollar had been placed in an investment in which earnings were taxed year-by-year.

$$
\begin{aligned}
& \text { value of } \operatorname{tax}=(1+r)^{n}-\tau_{c}\left[(1+r)^{n}-1\right]-\left[1+r\left(1-\tau_{c}\right)\right]^{n} \\
& \text { deferral of earnings }
\end{aligned}
$$

${ }^{15}$ This arrangement is chosen so that the comparison can be made on a risk-free basis. There are a number of investment alternatives where the corporation can defer the taxes on at least some part of its returns. However these alternatives are rarely as riskless as are bonds held in the pension fund.

${ }^{16}$ This is the relevant case for contributions made in excess of the maximum tax-deductible limit. It is important since actuarial procedures permitted by the IRS do significant1y limit the amount that can be deducted in a given year. See Jackson [4]. 
The value of the tax deferral stems from the compounding of investment earnings at the pre-tax rate of return and then paying the tax only on the interest accumulated. The economic benefit is equal to the after-tax accumulated interest on the deferral of tax payments on interest earned. This is shown next.

The tax deferral in period $(t)$ is equal to the tax that would have been paid on the return on the firm's investment in that period. The firm's investment in that period is the amount that would have accumulated had the firm been paying taxes on earnings up to that point. The deferral will accumulate interest from period ( $t$ ) to period ( $n$ ) at which time taxes are paid on the accumulated interest. The after-tax return on the sum of each period's deferral is given by

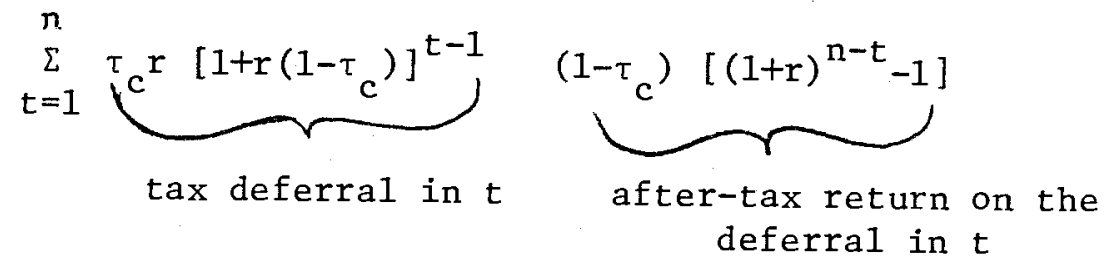

which is equal to

$$
\left(1-\tau_{c}\right)\left[(1+r)^{n}-\left(1+r\left(1-\tau_{c}\right)\right)^{n}\right]+\tau_{c}\left[1-\left(1+r\left(1-\tau_{c}\right)\right)^{n}\right]
$$

which is equal to equation (1).

In the second situation, contributions can be deducted imrediately, in addition to earnings not being taxed. Every dollar of the firm's after-tax investment in the pension fund is augmented by the deferred tax payment $\tau_{c} /\left(1-\tau_{c}\right)$, so that the pension fund has a total amount invested of $1 /\left(1-\tau_{c}\right)$. This amount accumulates at the pension fund rate of return over the $n$ years at which time the contribution is reduced. The full value of this accumulation is taxable since the deduction for the contribution has already been taken. The firm earns, after-tax, an amount equal to $\left(1-\tau_{c}\right) \cdot\left(1 / 1-\tau_{c}\right)(1+r)^{n}$, so that with both 
tax deferrals operating the firm earns the pre-tax rate of return on the pension fund. ${ }^{17}$ The value of the deductibility of contributions given by equation 2 below can be established by subtracting from this accumulated return on investment the return the firm would earn in the previous case where on1y taxes on earnings are deferred.

$$
\begin{aligned}
& \text { value of } \operatorname{tax}=\tau_{c}\left[(1+r)^{n}-1\right] \\
& \text { deferral on } \\
& \text { contributions }
\end{aligned}
$$

This amount is the after-tax return accumulated on the tax deferral resulting from the deduction of the contribution since the contribution of $\$ 1.00$ resulted in a deferral of $\frac{\tau_{c}}{1-\tau_{c}}$ dollars and the after-tax return on the deferral is

$$
\frac{\tau_{c}}{1-\tau_{c}} \cdot\left(1-\tau_{c}\right)\left[(1+r)^{n}-1\right]
$$

$\overline{17}$

Another way of saying this is that the return on the pension is equivalent to a return on corporate investments in which no taxes are paid. Therefore, on1y if the firm has riskless investment opportunities similar to bonds in the pension fund in which taxes on the returns are deferred for significant time periods so that it effectively earns close to the pre-tax rate, will the pension fund will not be as attractive a use of funds and the tax provisions will not be much of an incentive. 
Figure 1 shows the values of each of the two tax deferral provisions for a pension fund return of $10 \%$ and a corporate tax rate of $50 \%$. It shows that when the deferral period is short the deferral due to the deduction of contributions dominates. The deferral of taxes on earnings is not important when an immediate deduction is not allowed because the accumulation of earnings is small relative to the principal invested. Taken together the two tax provisions amount to an exemption of taxes independent of the ... horizon. The tax on earnings deferral begins to become significant when the deferral period approximates ten years. It increases the dollar return on the company's investment at the end of ten years by approximately $10 \%$ which is equivalent to an increase in the compound return from the after-tax rate at $5 \%$ to approximately $6 \%$. This effect is approximately $20 \%$ of the total return enhancement that takes place when both tax deferral provistons takes place. It takes approximately 50 years before the impact of the two provisions are about equal. 


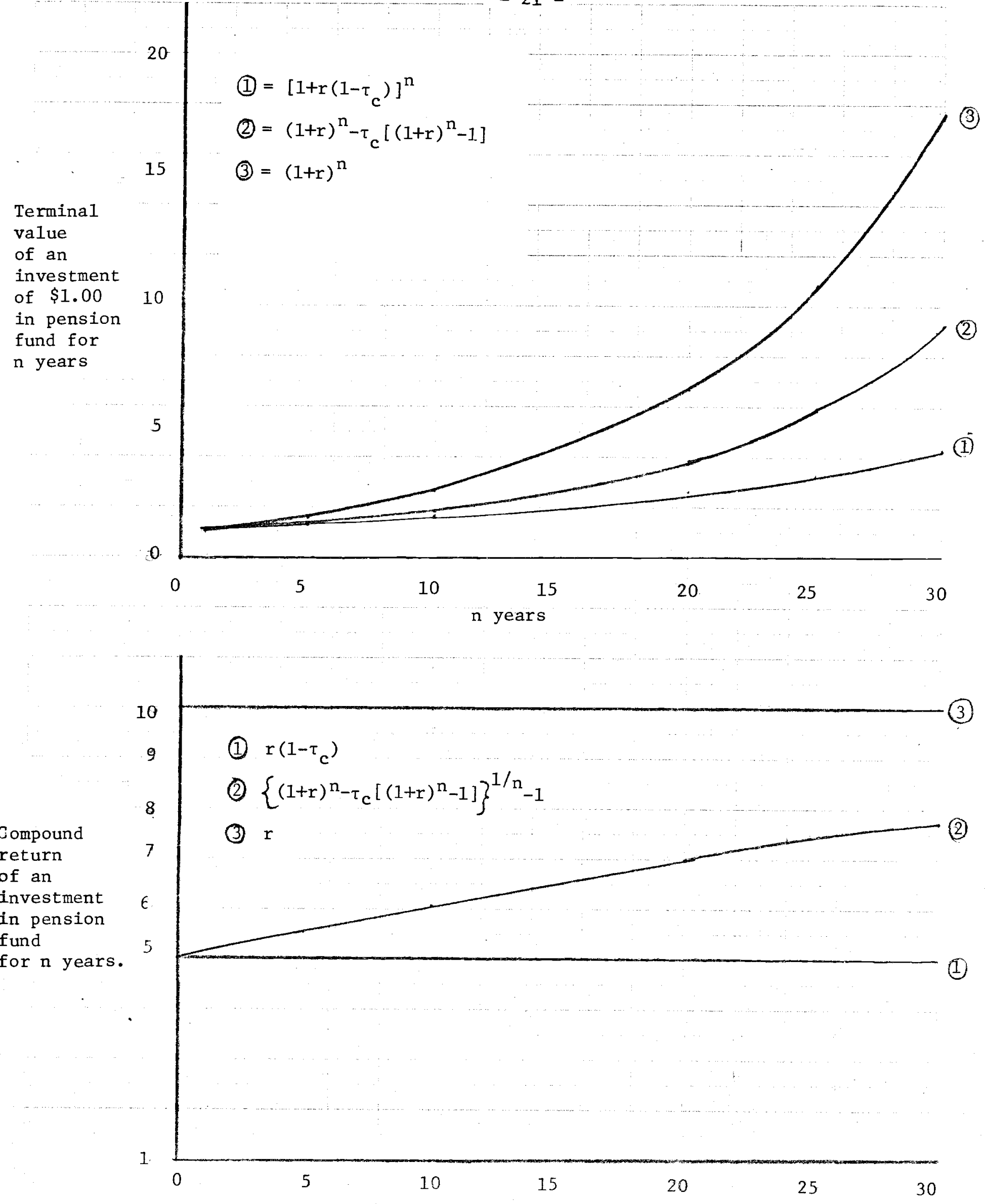

Figure 1: Accumulated Values and Compound Return for an Investment in Pension Fund as a Function of Horizon. 


\section{References}

1. F. Black. "The Investment Policy Spectrum: Individuals, Endowments and Pension Funds." Financial Analysts Journal, (January-February 1976).

2. F. Black. "The Tax Consequences of Iong-Run Pension Policy," Financial Analysts Journal, (July/August, 1980).

3. E.F. Fama. "The Effects of a Firm's Investment and Financing Decisions on the Welfare of its Security Holders." American Economic Review, (June 1978).

4. P.H. Jackson. "Investment Aspects of Pension Fund Prepayments." Proceedings of the Conference of Actuaries in Public Practice, Vol. 27 (1977-1978).

5. Johnson and Higgins. Funding Costs and Liabilities of Large Corporate Pension Plans. (1979).

6. M.H. Miller. "Debt and Taxes." Journal of Finance, (May 1977).

7. M.S. Scholes. "Executive Compensation, Pension Funding, Signalling and Taxation." Paper presented at AFA meetings, (December 1979).

8. W.F. Sharpe. "Corporate Pension Funding Policy." Journal of Financial Economics, (June 1976).

9. I. Tepper and A.R.P. Affleck. "Pension Plan Llabilities and Corporate Financial Strategies." Journal of Finance, (December 1974).

10. and R.D. Paul. "How much funding for your company's pension plan?" Harvard Business Review, (November-December 1978).

11. J.L. Treynor, Regan and Priest. The Financial Reality of Pension Funding Under ERISA, Dow Jones-Irwin (1976).

12. C.L. Trowbridge. "Fundamentals of Pension Funding." Transactions of the Society of Actuaries, (1952). 